\title{
Exploring Diversity and Student Political Activism through Archival Research
}

Laurel Elder, Hartwick College

Shelley Wallace, Hartwick College

ABSTRACT In 2011, the American Political Science Association stated that integrating issues of diversity, inclusiveness, and equality into political science curriculum and pedagogy was crucial to the success of the discipline in the twenty-first century. Although consensus is forming about the need to teach diversity, the question of how to do this effectively remains open. This article describes an archives-based assignment in an introduction to American government course created by the authors of this article-a professor of political science and the college archivist-that includes greater understanding of diversity and engaged citizenship as learning objectives. For this assignment, students are immersed in archival material about their own college and tasked with analyzing the political actions of previous generations of students as the civil rights and women's movements emerged, as the student population became more diverse, and as the campus reacted to national and local events relating to racial intolerance and injustice. By examining their college's political past-both the conflicts that animated the community and the student-led efforts to make the campus more inclusivecurrent students engage with issues of diversity and political activism in a way that helps them better understand themselves and their role as citizens in a democratic nation.

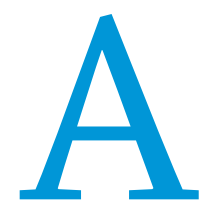

number of colleges and universities are integrating a focus on diversity into their curricula (Deruy 2016), with many doing so to create more tolerant communities in response to hate crimes on campus (Bauman to address the experiences of today's increasto democracy and equality, political science faculty believe they have a special responsibility to teach about diversity (Bauer and Clancy 2018; Rasmussen 2014). In 2011, the American Political Science Association (APSA) stated that integrating issues of diversity, inclusiveness, and equality into political science curriculum and pedagogy was crucial to the success of the discipline in the twenty-first century (APSA 2011). Although consensus is forming about the need to teach diversity, the question of how to do this effectively remains open.

This article describes an archives-based assignment in an introduction to American government course created by the authors of this article-a professor of political science and the

Laurel Elder (iD) is professor of political science at Hartwick College. She can be reached at elderl@hartwick.edu.

Shelley Wallace is the Hartwick College archivist. She can be reached at wallaces@ hartwick.edu. college archivist-that includes greater understanding of diversity and engaged citizenship as learning objectives. For this assignment, students are immersed in archival material about their own college and tasked with analyzing the experiences and political actions of previous generations of students as the civil rights and women's movements emerged, as the student population became more diverse, and as the campus reacted to national and local events relating to racial intolerance and injustice. By examining their college's political past-both the conflicts that animated the community and the student-led efforts to make the campus more inclusive-current students engage with issues of diversity and political activism in a way that helps them better understand themselves and their role as citizens in a democratic nation. Using analytical and interpretive skills with primary sources also empowers students as active researchers. This assignment was designed for a political science course at a liberal arts college; however, it can be used at all types of institutions and in many different disciplines-as long as they have an accessible archives and an archivist willing to partner in the project.

\section{LEARNING OBJECTIVES}

One objective of this assignment is to cultivate an understanding of diversity, defined by our college's diversity requirement 
as having students "recognize human diversity and analyze the sources and consequences of inequality, marginalization, and privilege." To achieve this objective, the American government class in which this assignment takes place draws on an intersectional pedagogy. Starting from the premise that "inequality is deeply entrenched in the policies and institutions of American democracy" (Junn 2004, 255), the course uses supplemental readings and structured class discussions to foreground "power and processes." It draws on multiple identities including race, ethnicity, and gender as a lens for understanding each topic (Rasmussen
Over the twentieth century, the student body at Hartwick and SUNY Oneonta became more racially and ethnically diverse. What tensions emerged as nonwhite students were integrated into the Oneonta colleges? What demands were made by different groups and what was the response by students, administrators, and the broader Oneonta community? How do racial issues at Hartwick today compare with past decades?

For most students, working in archives and researching with primary-source material are new experiences. Therefore, the

\section{By examining their college's political past-both the conflicts that animated the community and the student-led efforts to make the campus more inclusive-current students engage with issues of diversity and political activism in a way that helps them better understand themselves and their role as citizens in a democratic nation.}

2014, 102). Exploring the causes and consequences of inequality and the lived experiences of marginalized groups is crucial to understanding every topic in the course from the US Constitution, which institutionalized the enslavement of black Americans, to federalism, which allowed and continues to allow states to disproportionately deny citizens of color the right to vote.

The archives assignment builds on the idea of "empathetic scaffolding"; that is, that students are best able to learn about potentially contentious issues such as diversity when they see a connection between the material and themselves (Bauer and Clancy 2018) and to have students engage in primary-source research about issues of marginalization and privilege at their own institution. Mutnick (2018) describes archival research this way: "Students encounter documents that reveal the history of the very streets they walk... Through their encounter with the archives, students learn to read closely, delve deeply, and connect personally and intellectually to their research."

A second objective is fostering engaged citizenship. By researching how their student predecessors voiced their concerns about diversity and inclusion and advocated for change, current students begin to think about themselves as political actors, identify changes they would like to enact, and assess different approaches to affecting change. Furthermore, having students piece together their own narrative based on primary sources helps them develop critical-thinking skills, which are vital for informed citizenship in our polarized political context (Yaco, Brown, and Lee 2016, 419).

\section{THE ASSIGNMENT AND THE ARCHIVAL EXPERIENCE}

After learning about the foundations of American government and the ways that privilege and inequality manifest in our political system, students enter the archives to begin their own primary-source explorations of how these issues are apparent at their own college. The professor and the archivist worked together to produce 10 different topics, including the civil rights movement, the black experience, gender equality, LGBTQ rights, and American Indian symbolism. (See the online appendix for the full assignment.) Students are given a set of questions to guide their research, tailored for each topic, but all of which ask students to identify and assess student political activism around issues of diversity. For example, for the topic "On Being Black at Hartwick: 1967-1970," the guiding prompt was as follows: archivist demonstrates the difference between a book search on the online catalog and searching Hartwick's online archival finding aid. She explains that books, as secondary sources, often interpret events for the reader, whereas primary sources are interpreted by the researcher. The students also receive a research-agreement form to read and sign, agreeing to the standard archival regulations: use of pencils only, gloves when working with photographs, no food or beverages, and careful handling of all documents. Rather than balking at these restrictions, students embrace the regulations as reflecting the unique work of researching with primary sources.

Most scholarly archival research requires months of reading through documents, only occasionally discovering relevant evidence. As an introductory archival experience, we provided a wide variety of primary sources-minutes of meetings, reports, newspapers, audio recordings, and photographs-grouped by relevance to the preselected topics. This strategy ensures that students are immersed in relevant documents without denying them a serendipitous discovery. Despite this preparatory work, students often were overwhelmed by the volume of archival information. Although notetaking is encouraged, the college archives also allows researchers to use phone cameras to take digital images of documents, thereby expediting their research. All of these challenges allow for enriching teaching moments in a primary-source research laboratory-the archives.

The students' next challenge is to complete a short written assignment constructing a preliminary thesis statement about diversity and political action related to their topic using quotations and other archival material to support their argument. This low-stakes, in-class assignment allows for the professor and archivist to provide tailored guidance to each student during the next archival session.

Students spend a total of three class periods (approximately 3 hours) in the archives, with access to the professor and the archivist for guidance in notetaking, citations, and development of their argument. Students then have the opportunity to return to the archives on their own. Many students come to appreciate and enjoy the archives during the course of the assignment. They return to work on their project but also to research other topics that they have discovered through their initial visits, thereby gaining a richer sense of their college's history. 
Ultimately, the students integrate their research into a paper, which draws on class readings and concepts to assess the nature, importance, and effectiveness of student actions and also addresses the specific prompts discussed previously. They present their findings to the class followed by questions and discussion. Finally, students reflect on their own and other students' archival projects in a final-exam essay question, provided to them in advance, as follows:

Based on class presentations, what are four interesting and important ways Hartwick students have advocated for change, and how would you evaluate the nature, value, and impact of these actions? Discuss one change you would like to see happen, why this change is needed, and what might be an effective way to bring about this change.

\section{STUDENT DISCOVERIES IN THE ARCHIVES}

The students' discoveries in the archives were both inspirational and sobering reminders of the challenges of diversity and inclusion at our predominantly white college in a predominantly white town. Students who selected the topic "Civil Rights at Hartwick College, 1963-1967" reviewed discussions of civil rights in Student Senate Minutes, Hilltops (the student newspaper), and the
The students' papers and presentations on this topic demonstrated that their archival research deepened their understanding of topics covered in class, such as the ways that racial inequality was embedded into the laws of Southern states and the role of collective action in pressuring the government to enact legislation. As one student wrote, "Hartwick College has always been a hub of intellectual conversation.... This was especially true during the 1960 .... During this time, many Southern states required that African Americans fulfill multiple tasks in order to achieve one of the most basic rights of American citizens: the right to vote. Due to this, many debates arose on campus on the issue of African American rights. These debates in particular stimulated the actions of student senate, graduates, and professors here at Hartwick College to change the ideals of those in the South from 1963 through 1965 that revolutionized the way that the campus thought about civil rights." Current students were particularly intrigued by the efforts of their predecessor to travel to the South to enact change, and they indicated that they now felt inspired to push for change themselves. Several of these students have done so at the college level by getting involved in student government and by advocating for causes on the national level.

Another group of students selected the topic "On Being Black at Hartwick: 1967-1970." This group considered the tensions

\section{The students' papers and presentations on this topic demonstrated that their archival research deepened their understanding of topics covered in class, such as the ways that racial inequality was embedded into the laws of Southern states and the role of collective action in pressuring the government to enact legislation.}

Oneonta Star (the local newspaper). They also had the opportunity to listen to audio tapes of civil rights leader James Farmer when he spoke on campus in 1965 and Jackie Robinson's civil rights talk on campus in 1967 , as well as to read newspaper coverage of these visits.

Several students who selected this topic chose to focus on the civil rights activities of one particular Hartwick college student, Bill Brault. After graduating in 1965, he decided to spend the summer engaging in voter-education and -registration activities among the black citizens of Greensboro, Alabama. He also took part in protests in response to the burning of three black churches and was jailed along with other civil rights protesters. According to the student newspaper account, "Nearly three hundred demonstrators were taken to a makeshift prison-Camp Selma.... The beds were taken out before they arrived and the only toilet was clogged. No blankets were provided; they had only the cold cement floor" (Hartwick Grad-Civil Rights Worker, Hilltops, September 24, 1965). Although the challenges were steep, this recent graduate was a firsthand witness to dramatic progress. In August 1965, President Johnson signed the Voting Rights Act, which banned tactics used by Southern states to disenfranchise black voters. "This had a profound impact on Bill's work. When Bill arrived in Greensboro, only 256 were registered in the county. During the next few weeks, the registrar added over three thousand to the rolls.... The biggest problem for the workers was to find enough transportation for all that wanted to register" (Hartwick Grad-Civil Rights Worker, Hilltops, September 24, 1965). that emerged as students of color began attending the two colleges in our town. Students in this group read a number of "Salt and Pepper" columns in the student newspaper written by the first black editorial columnist, Harold Nelson. The column vividly reveals the challenges of being one of few students of color on campus. In a column from April 5, 1967, Nelson wrote, "When I first came to Hartwick as a freshman, there were two Negroes in my class" (Hilltops 1967, 5). He continued by describing how during his time at the college, many people confused him with the only other black student on campus. The "Salt and Pepper" columnist also discussed that although he did not face explicit racism, he had the sense that not everyone appreciated his presence on campus.

Current students also were exposed to documents showing how students of color at both Hartwick and the other college in our town, SUNY Oneonta, sought to raise awareness about the challenges of being a minority student and to press for change. Articles in the school and local newspapers detailed how, in 1969, black students at SUNY Oneonta presented the president with a list of demands to increase diversity on campus. The demands included admitting more black students, hiring more black professors, establishing a black studies curriculum, and providing greater financial support for black students ("Oneonta State Black Students List Demands,” April 24, 1969). The local newspaper ran an editorial in response titled "Blacks' Demands Irk This Reader" (Oneonta Star, April 25, 1969). This "disgruntled Oneontan," as the column was signed, stated the following: 
"I think the colored students have a lot of nerve presenting Dr. Netzer with a petition of demands.... Why should my taxes increase to give $\$ 35$ to these lazy bums so they can stage sit-ins, and spend the money for LSD and marijuana? ... Another thing that makes my blood pressure rise is the demand that 200 colored students be brought here for the freshman class beginning in $1969 . .$. Why should the college lower the standards for them?"

A response to the black student demands by a group of white Hartwick students took a different approach but was similarly racist and demeaning. They published an article in the student newspaper titled "WASP Demands of Hartwick College Administration." The demands included having alcoholic beverages in residence halls, furnishing dorm rooms with mink carpeting, and allowing students to take all courses pass-fail. Present-day students reading this article were sometimes confused and only later realized that the white students were mocking the demands of the black students. They were shocked at the level of derision regarding demands that now seem reasonable.

Current students' archival discoveries helped them understand more viscerally the issues of white privilege and how advocating for equality often is met with hostility. They agreed that the college had progressed since the 196os but that more progress was needed to create a truly inclusive campus. Current students of color reflected on the shock they felt as they transitioned from their mostly black and Latino public high schools to our campus (i.e., only $21 \%$ African, Latino, Asian, and Native American), which felt overwhelmingly white, challenging to navigate socially, and often alienating. One student concluded that "Hartwick has come a long way from discrimination towards different racial groups. But that doesn't mean the presence of racism has disappeared at Hartwick; it is still here.... It lurks in the shadows of the Hartwick halls and dorms." Another student observed that "There still are not enough white students supporting the black community at Hartwick." Student presentations led to eye-opening discussions about the subtle and explicit ways that racism persists and shapes everyday social interactions, as well as the distribution of power on campus and in society (Tatum 2017).
Although it took time, women did start to mobilize for equal rights on campus. In 1979, students created the Women's Center and, in 1981, the group sponsored a conference "to provide women with viable role models for careers, to discuss potential conflicts, to explore how women's striving for success violates traditional expectations" (Women's Center Brochure). By the end of the 1980 , the student newspaper ran a series of articles on "Women and Social Change" that highlighted overlooked women in history. Several students contributed to a regular column, "Amazing Wimyn," which raised awareness about discrimination based on sexual orientation as well as the need to do more to address the AIDS epidemic.

Student papers showed how the archival research deepened their understanding of diversity, particularly the ways that gender shaped privilege and marginalization on their own campus and in their own town. One student wrote, "Women did not have the many rights attained today during the time period of 1950-1979 both on and off campus. On campus, women were told what to wear and how late to stay out.... Off campus, women experienced money prejudice, making it almost impossible to attain a banking account and to manage money." The assignment also helped students recognize the value of individual and collective action in creating the more equal environment that they now enjoy. One student wrote, "Women play a very important role at Hartwick College and in the whole world today. We as women are not as overlooked in society as we used to be and we can thank the many efforts of women's events and boards for women's studies across all colleges."

\section{ASSESSMENT AND DISCUSSION}

College provides an opportunity for people from diverse backgrounds to come together and learn from one another. However, whether students gain this invaluable knowledge depends on whether "the institution they attend has provided structures for those learning experiences to take place. Intentionality matters" (Tatum, quoted in Jaschik 2017). Our archives-based assignment intentionally creates a learning experience to help students better understand diversity and themselves as political actors with the capacity to work for greater equality.

\section{Current students' archival discoveries helped them understand more viscerally the issues of white privilege and how advocating for equality often is met with hostility.}

Other students focused on issues relating to women's rights during different periods as far back as 1929-1947. Student handbooks revealed that women had to follow a different set of rules than men. The 1941/42 handbook stated: "Every woman student...shall be in her rooming house not later than $11 \mathrm{pm}$. Proper ladylike decorum is expected." The 1956 handbook stated that women could only wear "slacks and blue jeans...in the college buildings on Saturday mornings." The student newspaper also featured the often-sexist cartoon, "Little Man on Campus," which was degrading to women. Contemporary students found this derogatory humor outrageous; however, through their archival research, they also realized that these sexist double standards were accepted by most students at the college at that time, as was the norm at many colleges.
The empathetic-scaffolding approach, which connects issues of power and privilege to the students' own campus, helped them engage with issues of diversity in a personal and powerful way. One student commented that after doing this assignment, he realized he was the only black student in his geology class. $\mathrm{He}$ then began using an intersectional lens to identify areas where he would like to see change on campus: greater ethnic and racial diversity among administrators, faculty, and staff. He is now a student member of a diversity taskforce seeking to address these issues. Several others students wrote about their perception that although gender equality is now a reality in many facets of their lives, women's sports teams were not always given the same resources as the men's teams and that this was an issue they now felt empowered to raise. 
Research documents how raising issues relating to diversity, inequality, and marginalization can produce student resistance (Bauer and Clancy 2018; Rasmussen 2014); indeed, some discomfort emerged in response to this assignment. In one instance, a student studying the reaction of the college to the Rodney King verdict commented that she felt uncomfortable discussing these issues "because I am white." The archivist then pointed her to an article in the student newspaper titled "Racism Is a White Problem," which helped her better understand that racial discrimination is not simply a problem for students of color. In other cases, doing this research brought to mind students' own experiences dealing with subtle or explicit discrimination. This assignment allowed them to place their experiences within a historical context and seemed to provide a constructive way to process their experiences and work with others to continue making the campus more inclusive.

Junn (2004) argued that civic education can be most effective when starting from an understanding of the inequalities pervasive in the American political system. We believe our assignment does just that. Whereas some students connected more personally with the assignment than others, all students confronted the reality that their own college-similar to most institutions of higher learning and government institutions-was originally structured around white male privilege. Although progress has been made toward greater equality, inclusivity, and tolerance on our campus, as in American politics more broadly, this progress was not inevitable. Indeed, a central theme running throughout student papers and final-exam answers was a recognition of the work their student predecessors had done, individually and collectively, to raise awareness about injustices and to advocate for change, as well as thoughtful explorations about how that work can be continued.

\section{SUPPLEMENTARY MATERIAL}

To view supplementary material for this article, please visit https://doi.org/10.1017/S1049096519001690

\section{REFERENCES}

Note: All archival citations are from the Paul F. Cooper, Jr., Archives at Hartwick College.

APSA Task Force on Political Science in the 21st Century. 2011. Political Science in the 21st Century. Washington, DC: American Political Science Association.

Bauer, Kelly, and Kelly Clancy. 2018. "Teaching Race and Social Justice at a Predominantly White Institution.” Journal of Political Science Education 14 (1): $72-85$.

Bauman, Dan. 2018. "Hate Crimes on Campuses Are Rising, New FBI Data Show." The Chronicle of Higher Education, November 14.

Deruy, Emily. 2016. "The Complicated Process of Adding Diversity to the College Syllabus." The Atlantic, July 29.

Jaschik, Scott. 2017. "Beverly Daniel Tatum Discusses New Version of 'Why Are All the Black Kids Sitting Together in the Cafeteria?" Inside Higher Ed, September 6.

Junn, Jane. 2004. "Diversity, Immigration, and the Politics of Education." PS: Political Science and Politics 37 (2): 253-55

Mutnick, Deborah. 2018. "The Appeal of the Archives: Engaging Students in More Meaningful Research." Available at TeachArchives.org.

Rasmussen, Amy Cabrera. 2014. "Toward an Intersectional Political Science Pedagogy.” Journal of Political Science Education 10: 102-16.

Tatum, Beverly Daniel. 2017. Why Are All the Black Kids Sitting Together in the Cafeteria? Anniversary Revised Edition. New York: Basic Books.

Yaco, Sania, Caroline Brown, and Konrad Lee. 2016. "Linking Special Collections to Classrooms: A Curriculum-to-Collection Crosswalk." American Archivist 79 (2): 417-32 (Fall/Winter). 